\title{
Stimulatory Effect of Shiitake Mushroom Extract on Curd Formation of Acid Milk by Lactic Acid Fermentation
}

\author{
Maynor VARGAS and Tomio OHASHI \\ Faculty of Agriculture, Miyazaki University, Miyazaki-shi 889-21
}

(Received July 5, 1996)

\begin{abstract}
Shiitake mushroom extract, obtained from industrial wastes of dry shiitake, was found to reduce the coagulation time of skim milk culture media by stimulating the bacterial growth of Lactobacillus delbrueckii subsp. bulgaricus B-5 b incubated at temperatures from 25 to $45^{\circ} \mathrm{C}$. It was observed that the stimulatory effect depended on the incubation temperature, being this effect stronger at $35^{\circ} \mathrm{C}$. The faster acidification of the culture media led to a rapid aggregation of casein with the formation of coarser gels. These samples showed great propensity to spontaneous syneresis, and the effect was intensified as incubation temperature increased.
\end{abstract}

Anim. Sci. Technol. (Jpn.) 67 (12) : 1090-1094, 1996

Key words : Shiitake mushroom extract, Acid milk curd, Coagulation time, Syneresis

Milk gel formation, as a result of fermentation or acidification, is very important in the manufacture of dairy products, and factors affecting the quality of the acid milk curd used as a raw material for products such as fresh cheese or fermented milk need to be considered in order to manufacture dairy foods of a higher quality ${ }^{2,1)}$.

On the other hand, one of the most popular mushrooms found in the Japanese diet is shiitake mushroom, Lentinus edodes, which is widely produced in Miyazaki Prefecture. However, only product of high quality is accepted from the plantation sites, and the large amount of dry mushroom flakes discarded represents a considerable source of contamination for the environment. Recently, some valuable cooked foods have been manufactured using a lower quality shiitake mushroom and on the process, a water extract is obtained from the rehydration step of the dry mushroom ${ }^{1)}$. Although this extract has been used as a flavor additive, it apparently contains many physiologically active substances that might find practical application in other fields ${ }^{7}$. However, little has been reported in such respect.

In the present paper, our objective was to observe the stimulatory effect of shiitake mushroom extract on the curdling and syneresis of skim milk culture media incubated with Lactobacillus delbrueckii subsp. bulgaricus B-5 $\mathrm{b}$ at different temperatures.

乳酸発醉によるミルク酸カード形成に対する椎葺エキスの促進效果：バルガス マイノル・大橋登美男（宮崎大学 農学部，宮崎书 889-21) 


\section{Materials and Methods}

\section{Preparation of shiitake mushroom extract}

One volume of dry shiitake mushroom graded low-quality was soaked in about 10 volumes of water at room temperature (15$20^{\circ} \mathrm{C}$ ) during 13 to $15 \mathrm{hr}$. The supernatant obtained was filtered, concentrated and pasteurized by heating to $95^{\circ} \mathrm{C}$. The general composition of the shiitake mushroom extract was determined in the conventional way, ${ }^{6,10}$. The extract contained $57.7 \%$ water, $2.52 \%$ total $\mathrm{N}, 9.60 \%$ total sugars, $6.76 \%$ ash, $450 \mathrm{mg} \% \mathrm{P}$ and $31 \mathrm{mg} \% \mathrm{Ca}$.

\section{Preparation of milk curd samples}

Portions of $1 \%$ shiitake mushroom extract were added to $20 \%$ reconstituted skim milk media, previously inoculated with $2 \%$ of a fresh culture starter of Lactobacillus delbrueckii subsp. bulgaricus $\mathrm{B}-5 \mathrm{~b}$, and kept at $5^{\circ} \mathrm{C}$ before use within $1 \mathrm{hr}$. Control samples were run parallel without the addition of the extract and acidities of the acid milk samples were determined every $3 \mathrm{hr}$ during $24 \mathrm{hr}$, as described elsewhere ${ }^{11}$. The general composition of the skim milk culture was determined according to the normal procedures ${ }^{6,11}$. The contents of moisture, whole protein, lactose, ash, $\mathrm{P}$ and $\mathrm{Ca}$ were $80.8 \%, 7.27 \%, 7.30 \%, 1.45 \%$, $226 \mathrm{mg} \%$ and $261 \mathrm{mg} \%$, respectively.

\section{Measurement of clotting times and synere-} sis

Clotting times were determined visually by observing the changes of the substrate in the flask, i.e., the appearance of a heterogeneous flow and of first traces of coagulum on the inner surface when the flask was gently tipped $^{33}$.

On the measurement of syneresis, the curd formed in a beaker was retained by means of a wire grid placed on top of it. This enabled the whey to be poured off easily at time intervals for measurement of its volume ${ }^{8)}$.

\section{Results and Discussion}

Fig. 1 shows the effect of the incubation temperature and incubation time on the formation of acid milk curd in $20 \%$ skim milk culture media, with and without the addition of shiitake mushroom extract.

Clotting times were decreased by increased temperature and the effect of the addition of the extract was considerable. At $15^{\circ} \mathrm{C}$, the activity of the lactic acid bacteria was apparently too low for the samples to curdle, even in the presence of the extract. This effect was first noticed at $25^{\circ} \mathrm{C}$, when a 7 -hr difference in the coagulation time was observed. At higher incubation temperatures, this effect was less pronounced; 4 and 3-hr differences for samples incubated at 35 and $45^{\circ} \mathrm{C}$, respectively.

The use of a rather high concentration of skim milk in the culture media seems to have been responsible for the absence of syneresis in the not-supplemented samples, even after an incubation period of $24 \mathrm{hr}$. However, when shiitake mushroom extract was added, syneresis took place at 15 and $12 \mathrm{hr}$, in samples in cubated at 35 and $45^{\circ} \mathrm{C}$, respectively, and around 15 and $50 \%$ of whey had separated from the curd after $24 \mathrm{hr}$ of incubation, respectively.

Changes in acidity during the fermentation process at the different temperatures are shown in Fig. 2. According to Morichi ${ }^{9)}$, and Smith et al. ${ }^{12)}$, these values can be used as an indirect measure of the growth of lactic acid bacteria in milk. In the absence of the extract the lactic acid bacteria grew better at 45 than at $35^{\circ} \mathrm{C}$. However, the stimulatory effect of the extract was apparently not the same at different temperatures; the growth stimulation became stronger as temperature increased from 15 to $35^{\circ} \mathrm{C}$, but was less pronounced at $45^{\circ} \mathrm{C}$.

By comparing Fig. 1 and Fig. 2, it could be deduced that at different incubation temperatures, clotting times not only were shortened by the presence of the extract, but also that for 


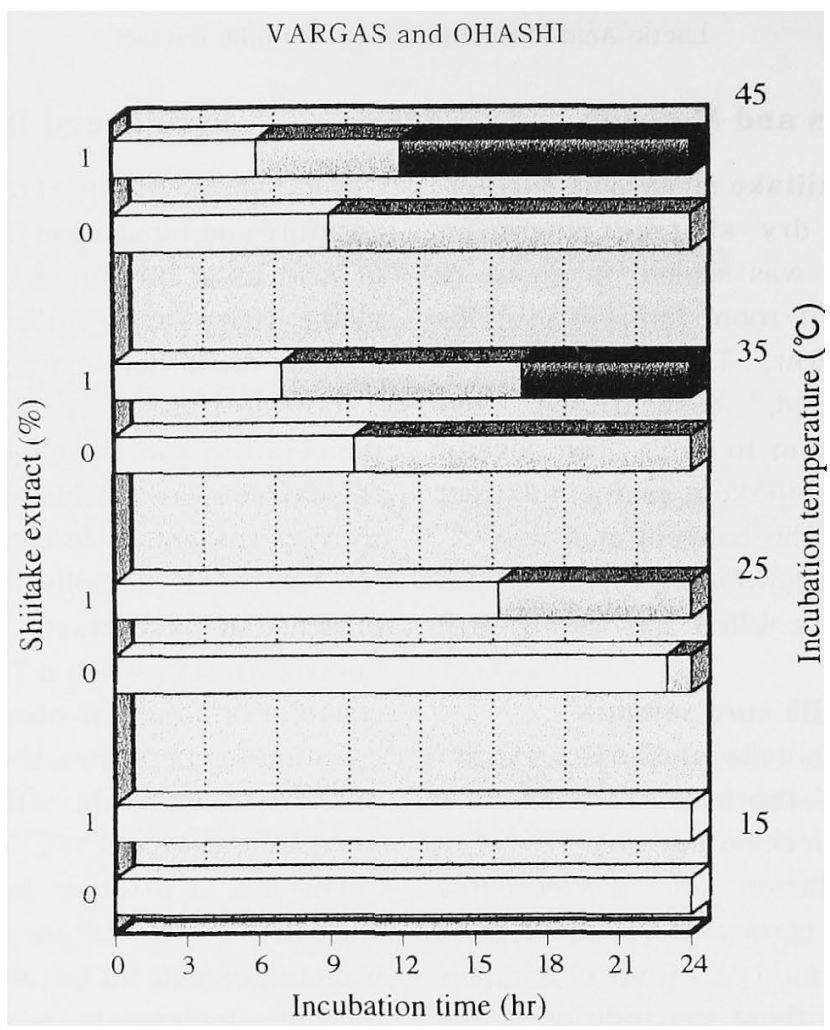

Fig. 1. Effect of incubation temperature on curd formation and syneresis of skim milk samples.

$\square$ not curdled $\square$ curdled $\square$ syneresis

a given temperature, increasing the rate of gelation resulted in the onset of gelation at a slightly lower acidity value. At 35 and $45^{\circ} \mathrm{C}$, not-supplemented samples clotted when acidity was approximately 0.58 and 0.63 , but in its presence these values were about 0.53 and 0.45 , respectively. In the not-supplemented samples the acidification of skim milk media took place more slowly, what probably gave more time to the casein network to form a firmer and more continuous gel with less tendency to undergo subsequent syneresis ${ }^{4}$. In supplemented samples, the first signs of syneresis were detected with acidity values of 1.73 and 0.95, respectively, in contrast to the notsupplemented samples showing similar acidities.

Syneresis of curd results from mainly hydrophobic interactions within the casein network, what makes the curd shrink and exert a pressure on the entrapped moisture forcing it out through the matrix pores, and any external factor that can reduce the hydrophobicity of the casein micelles, such as a temperature increase, would lead to a reduction in clotting times, and consequently to a rapid aggregation of casein with the formation of large dense aggregates which precipitate rather than form a gel ${ }^{2,4)}$. This accorded with the observation that syneresis increased by raising the temperature, what increased the energy available for hydrophobic interactions, i.e., a reduction in repulsive forces among the casein micelles. Besides, a faster lactic fermentation promoted by the presence of the extract contributed to form a coarser network with a greater propensity to spontaneous syneresis. 
Lactic Acid Fermentation by Shiitake Extract
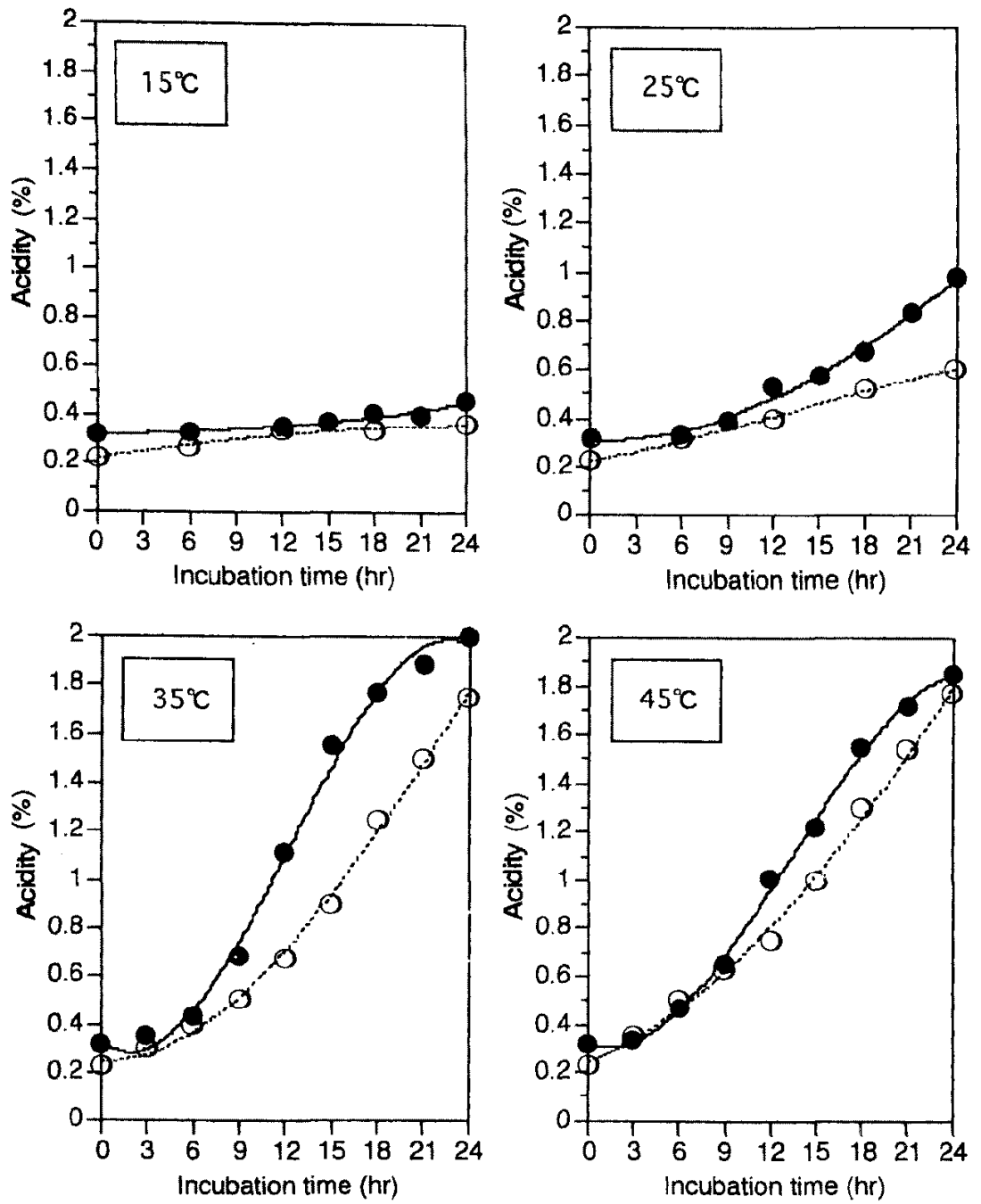

Fig. 2. Effect of the addition of $1 \%$ shiitake mushroom extract on the lactic acid fermentation at various temperatures, expressed as the variation of acidity during a $24 \mathrm{hr}$ incubation period.

(O), control samples; (-), extract-added samples.

In this experiment, syneresis was strongly stimulated by the extract addition around the optimal incubation temperature range of Lactobacillus delbrueckii subsp. bulgaricus $\mathrm{B}^{-} 5 \mathrm{~b}^{9}$. Depending on the final utilization of the curd obtained, separation of whey might become an undesirable property, and since higher incubation temperatures of fermented milks, all other factors being equal and provided starter growth is not inhibited, promote coarser gel networks, it should be considered to incubate samples at lower temperatures and/or the use of a higher milk solids concentration ${ }^{13)}$. Many other factors may have influenced not only the final gel structure but also the gelation rate, the degree of structure at different $\mathrm{pH}$ values, and the $\mathrm{pH}$ at which gelation is initiated. So, a more detailed investigation should be done on 


\section{VARGAS and OHASHI}

this respect

\section{References}

1) Aoyagi Y, Sugahara T. Studies on the rehydration of dry shitake mushroom. Nippon Shokuhin Kogyo Gakkaishi, 33 : 244-249. 1986.

2) Cobos A, Hornes DS, Muir DD. Rheological properties of acid milk gels. I. Effect of composition, process and acidification conditions on products from recombined milks. Milchwissenschaft, $50: 444-448.1995$.

3) Garnot P, Corre C. Influence of milk protein concentration on the gelling activity of chymosin and bovine pepsin. J. Dairy Sci., $47: 103-111.1980$.

4) Guinee TP, Pudja PD, Farkye NY. Fresh acidcurd cheese varieties. In : Cheese : Chemistry, Physics and Microbiology. Vol. 2. 2nd edition (Fox PF ed.) 363-419. Chapman \& Hall. London. 1993.

5) Harwalkar VR, Kalab M. Susceptibility of yogurt to syneresis. Milchwissenschaft, 38 : 517-522. 1983.

6) Hirataka $Y$, Hetsuka $K$, Ohashi $T$. Calcium determination in laying hen plasma and shell gland fluid by atomic absorption spectroscopy. J. Jpn. Soc. Food Nur., $28: 505-508.1975$.

7) Kawai K. Utilization of mushrooms. 67-105, 107-114. Chikuchi Shokan. Tokyo. 1988.

8) Marshall R. An improved method for the measurement of the syneresis of curd formed by rennet action on milk. J.Dairy Res., $49: 329$ 336. 1982.

9) Morichi T.Practical Handbook of Manufacture Technology in Dairy Industry. 18, 43. Soken Shuppan. Tokyo. 1984.

10) Ohara $T$, Suzuki $R$ Iwao $Y$. Handbook of Food Analysis. 17-23, 32-38, 248, 262-265. Kenpakusha. Tokyo. 1969.

11) Pharmaceutical Society of Japan. Standard Methods of Analysis of Milk and Milk Products. 126-135. Kanehara Shuppan Co. Tokyo. 1984.

12) Smith SJ, Hillier AJ, Lees GJ. The nature of the stimulation of the growth of Streptococcus lactis by yeast extract. J. Dairy Res., 42 : 123138. 1975.

13) Tamime A, Robinson R. Fermented milks and their future trends. Part II. Technological aspects. J. Dairy Res., 55 : 281-307. 1988. 